Article

\title{
Alkali-metal-modified ZSM-5 zeolites for improvement of catalytic dehydration of lactic acid to acrylic acid
}

\author{
Chuan Yuan a, Huayan Liu a, Zekai Zhang a, Hanfeng Lua ${ }^{a}$, Qiulian Zhu a, Yinfei Chen a,b,* \\ a College of Chemical Engineering, Zhejiang University of Technology, Hangzhou 310014, Zhejiang, China \\ ${ }^{\mathrm{b}}$ Zhejiang Province Key Laboratory of Green Chemistry and Technology, Zhejiang University of Technology, Hangzhou 310014, Zhejiang, China
}

A R T I C L E I N F O

Article history:

Received 3 June 2015

Accepted 6 September 2015

Published 20 November 2015

Keywords:

ZSM-5 zeolite

Alkali metal

Lactic acid

Acrylic acid

Dehydration

\begin{abstract}
A B S T R A C T
Various ZSM-5 zeolites modified with alkali metals ( $\mathrm{Li}, \mathrm{Na}, \mathrm{K}, \mathrm{Rb}$, and $\mathrm{Cs}$ ) were prepared using ion exchange. The catalysts were used to enhance the catalytic dehydration of lactic acid (LA) to acrylic acid (AA). The effects of cationic species on the structures and surface acid-base distributions of the ZSM-5 zeolites were investigated. The important factors that affect the catalytic performance were also identified. The modified ZSM- 5 catalysts were characterized using X-ray diffraction, temperature-programmed desorptions of $\mathrm{NH}_{3}$ and $\mathrm{CO}_{2}$, pyridine adsorption spectroscopy, and $\mathrm{N}_{2}$ adsorption to determine the crystal phase structures, surface acidities and basicities, nature of acid sites, specific surface areas, and pore volumes. The results show that the acid-base sites that are adjusted by alkali-metal species, particularly weak acid-base sites, are mainly responsible for the formation of AA. The KZSM- 5 catalyst, in particular, significantly improved LA conversion and AA selectivity because of the synergistic effect of weak acid-base sites. The reaction was conducted at different reaction temperatures and liquid hourly space velocities (LHSVs) to understand the catalyst selectivity for AA and trends in byproduct formation. Approximately 98\% LA conversion and 77\% AA selectivity were achieved using the KZSM- 5 catalyst under the optimum conditions (40 wt $\%$ LA aqueous solution, $365^{\circ} \mathrm{C}$, and LHSV $2 \mathrm{~h}^{-1}$ ).
\end{abstract}

(C) 2015, Dalian Institute of Chemical Physics, Chinese Academy of Sciences. Published by Elsevier B.V. All rights reserved.

\section{Introduction}

Biomass conversion has recently become a research hotspot because of environmental deterioration and shortages of nonrenewable fossil fuel resources such as oil and coal [1,2]. Lactic acid (LA), a biomass with hydroxyl and carboxyl groups, can be converted to other chemicals $[3,4]$ such as acetaldehyde (AD) [5], propionic acid (PA) [6], acrylic acid (AA) [7], and 2,3-pentanedione (2,3-P) [8]. AA is commonly used in the synthesis of functional materials, including superabsorbent resins [9], and is produced mainly by two-step oxidation of propylene derived from the petrochemical industry. The production of AA from propylene will be difficult to sustain because of potential petroleum shortages in a few decades, therefore a sustainable route, namely one-step dehydration of LA (or LA derivatives) to $\mathrm{AA}$, has attracted much attention [10]. Catalysts such as sulfates $\left(\mathrm{BaSO}_{4}\right)$ [11], phosphates $\left(\mathrm{Ca}_{3}\left(\mathrm{PO}_{4}\right)_{2}-\mathrm{Ca}_{2}\left(\mathrm{P}_{2} \mathrm{O}_{7}\right)\right)$ [12], and $\mathrm{NaY}$ and $\beta$ zeolites [13-15] have been reported for LA dehydration; this suggests that moderate surface acid-base strength and density are crucial for efficient catalysis of LA dehydration to AA. However, sulfate and phosphate catalysts only work efficiently at high temperature $\left(400{ }^{\circ} \mathrm{C}\right)$ because of the limited number of surface active sites. A high temperature promotes decarbonylation, decarboxylation, and coking of hydrocarbon compounds, resulting in feedstock waste $[11,16]$. Zeolite catalysts with high surface acidities and basicities can catalyze LA

* Corresponding author. Tel: +86-13606643528; E-mail: yinfei.chen@gmail.com 
dehydration to unsaturated acids at low temperatures. $\mathrm{KI} / \mathrm{NaY}$ gives a good catalytic performance in terms of LA conversion (97.6\%) and AA selectivity $(67.9 \%)$ at $325{ }^{\circ} \mathrm{C}$ and a liquid hourly space velocity (LHSV) of $2.25 \mathrm{~h}^{-1}$. Yan et al. [15] used alkali-metal-modified $\beta$ zeolites as catalysts and obtained an AA yield of $61 \mathrm{~mol} \%$ using the best catalyst, i.e., $\mathrm{K}_{0.94 \mathrm{Na}} \mathrm{Na}_{06} \beta$. However, NaY zeolites have numerous strong acid surface sites and three-dimensional supercages, which facilitate carbon deposition, resulting in fast zeolite deactivation of zeolites [17].

ZSM-5 zeolites have been used in alcohol dehydration because of their adjustable surface acidities and basicities and the absence of supercages [18,19]. There has as yet been no report of the catalytic dehydration of LA using ZSM-5 zeolites. In this study, ZSM-5 zeolites modified with alkali metals using an ion-exchange method to adjust the strengths and densities of the surface acidity and basicity were used to catalyze LA dehydration to AA. Coking inhibition and improved catalytic selectivity were expected.

\section{Experimental}

\subsection{Materials}

LA (analytical grade) was purchased from the Hangzhou Shuanglin Chemical Reagent Co. Alkali metal (Li, $\mathrm{Na}, \mathrm{K}, \mathrm{Rb}$, and Cs) nitrates, AA, AD, PA, 2,3-P, and isopropanol were obtained from the Aladdin Reagent Co.

\subsection{Catalyst preparation}

ZSM-5 zeolite (Si/Al molar ratio $=75$; Shanghai Shentan Environmental New Materials Co., Ltd., China) was preheated at $550{ }^{\circ} \mathrm{C}$ for $6 \mathrm{~h}$ and treated with an aqueous solution of $\mathrm{MNO}_{3}(1$ $\mathrm{mol} / \mathrm{L} ; \mathrm{M}=\mathrm{NH}_{4}, \mathrm{Li}, \mathrm{Na}, \mathrm{K}, \mathrm{Rb}$, or Cs; $14 \mathrm{~g}$ of ZSM-5 zeolite in 140 $\mathrm{mL}$ of $\mathrm{MNO}_{3}$ ) at $80{ }^{\circ} \mathrm{C}$ for $6 \mathrm{~h}$ to obtain ion-exchanged ZSM-5. The treated ZSM-5 zeolites were filtered and washed at least three times with distilled water to remove excess $\mathrm{MNO}_{3}$. The catalysts were dried at $110{ }^{\circ} \mathrm{C}$ for $12 \mathrm{~h}$ and calcined at $550{ }^{\circ} \mathrm{C}$

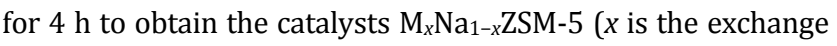
degree of $\mathrm{M}^{+}$, i.e., the molar ratio of $\mathrm{M}^{+} /\left(\mathrm{Na}^{+}+\mathrm{M}^{+}\right)$, determined using X-ray fluorescence), which are denoted by HZSM-5, LiZSM-5, NaZSM-5, KZSM-5, RbZSM-5, and CsZSM-5. All the modified ZSM-5 catalysts were prepared under identical conditions.

\subsection{Catalyst characterization}

Powder X-ray diffraction (XRD) was performed using an X' Pert PRO instrument operated at $40 \mathrm{kV}$ and $30 \mathrm{~mA}$, with $\mathrm{Cu} K_{\alpha}$ radiation; the patterns were recorded at $2 \theta=10^{\circ}$ to $60^{\circ}$ at a rate of $5 \% \mathrm{~min}$. The surface acidity and basicity were investigated using $\mathrm{NH}_{3} / \mathrm{CO}_{2}$ temperature-programmed desorption (TPD; Chem-Adsorption Finesor-30102). The nature of the surface acid sites (Brønsted or Lewis acid) was determined using pyridine adsorption Fourier-transform infrared (Py-IR) spectroscopy in the range of $600-4000 \mathrm{~cm}^{-1}\left(2 \mathrm{~cm}^{-1}\right.$ resolution; Vertex 70 spectrometer). Thermogravimetric analysis (TGA) was performed using a thermal analyzer (STA409PC, Netzsch) at $20-650{ }^{\circ} \mathrm{C}$ with a heating rate of $10{ }^{\circ} \mathrm{C} / \mathrm{min}$ in air. The Brunauer-Emmett-Teller (BET) specific surface areas and pore volumes of the samples were determined by $\mathrm{N}_{2}$ adsorption (3Flex, Micromeritics). Elemental analysis was performed using a Shimadzu XRF-1800 spectrometer.

\subsection{Catalytic reaction}

The catalytic dehydration of LA to AA was performed in a continuous-flow fixed-bed reactor (inner diameter $8 \mathrm{~mm}$ ) at atmospheric pressure. The pelletized catalysts (0.8-1.2 g, 20-40 mesh) were placed in a quartz reactor and pretreated for 30 min under $\mathrm{N}_{2}$ flow. The reactant (40 wt\% LA aqueous solution) was pumped into a vaporizer using a micro-injection pump, and the vapor was carried through the catalyst bed by $\mathrm{N}_{2}\left(30 \mathrm{~mL} / \mathrm{min}, \mathrm{LHSV}=2-4 \mathrm{~h}^{-1}\right)$. The outlet products were condensed and then analyzed using a gas chromatography system (Agilent 6890) with an Innowax capillary column and flame ionization detector. Isopropanol was used as the internal standard for liquid product analysis.

\section{Results and discussion}

\subsection{Catalyst performance}

\subsubsection{Catalytic reaction results}

Alkali-metal-modified ZSM-5 zeolites were used to catalyze LA dehydration. The products and selectivity data are listed in Table 1. The main product was AA, with $\mathrm{AD}, 2,3-\mathrm{P}$, and PA as the main byproducts; other byproducts included pyruvic acid, acetic acid, and gaseous products. The modified zeolites gave

Table 1

Performance of different ion-exchanged ZSM-5 catalysts for LA dehydration.

\begin{tabular}{|c|c|c|c|c|c|c|c|c|}
\hline \multirow{2}{*}{ Catalyst } & \multirow{2}{*}{$\begin{array}{c}\text { LA conversion } \\
(\%)\end{array}$} & \multicolumn{5}{|c|}{ Selectivity (\%) } & \multirow{2}{*}{$\begin{array}{l}\text { AA formtion rate } \\
\left(\mathrm{mmol} \mathrm{g}^{-1} \text { cat } \mathrm{min}^{-1}\right)\end{array}$} & \multirow{2}{*}{$\begin{array}{l}\text { Carbon deposits } \\
\left(\mathrm{mg} \mathrm{g}^{-1} \text { cat }^{-1}\right)\end{array}$} \\
\hline & & AA & $\mathrm{AD}$ & $2,3-\mathrm{P}$ & PA & Others $^{\text {a }}$ & & \\
\hline HZSM-5 & 99.88 & 1.43 & 40.13 & 0.02 & 0.48 & 57.94 & 0.011 & 27.50 \\
\hline LiZSM-5 & 97.69 & 38.20 & 31.56 & 0.74 & 0.56 & 28.94 & 0.141 & 10.04 \\
\hline NaZSM-5 & 94.47 & 51.69 & 17.33 & 0.45 & 0.82 & 29.71 & 0.180 & 8.63 \\
\hline KZSM-5 & 91.24 & 70.29 & 15.17 & 0.66 & 0.64 & 13.24 & 0.231 & 8.75 \\
\hline RbZSM-5 & 91.86 & 56.22 & 15.40 & 3.42 & 1.92 & 23.04 & 0.175 & 11.25 \\
\hline CsZSM-5 & 85.33 & 62.01 & 15.15 & 0.45 & 0.82 & 21.57 & 0.189 & 7.78 \\
\hline
\end{tabular}

Reaction conditions: RT, $350{ }^{\circ} \mathrm{C} ; 40 \mathrm{wt} \%$ LA aqueous solution, $0.8 \mathrm{~mL} / \mathrm{h}$; carrier gas, $50 \mathrm{~mL} / \mathrm{min}$; catalyst, $2 \mathrm{~mL}(0.9 \mathrm{~g})$; time on stream (TOS) = $8 \mathrm{~h}$. a Others: pyruvic acid, acetic acid, carbon deposit, gaseous products $\left(\mathrm{CO} / \mathrm{CO}_{2}\right.$ and $\left.\mathrm{H}_{2}\right)$. Selectivity for others = $100 \%-$ the total selectivity for each listed products. ${ }^{\mathrm{b}}$ Accumulated in $8 \mathrm{~h}$ reaction time. 


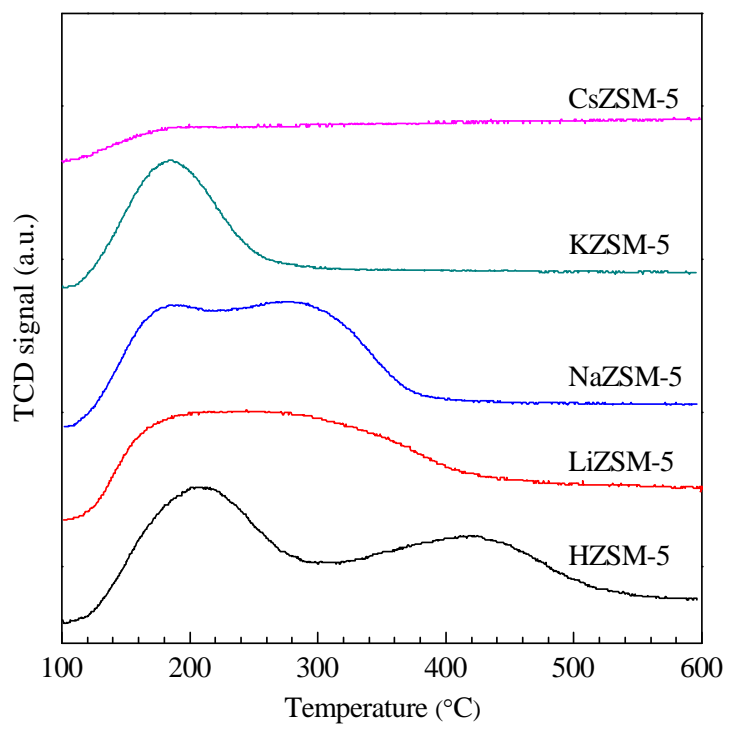

Fig. 1. $\mathrm{NH}_{3}$-TPD profiles of catalysts.

enhanced catalytic performance in LA dehydration to AA. LA conversion decreased in the following order $\mathrm{H}->\mathrm{Li}->\mathrm{Na}->\mathrm{K}-$ $>\mathrm{Rb}$ - > Cs-modified ZSM-5; the AD selectivity decreased from HZSM-5 to CsZSM-5. The highest AA selectivity was obtained using the KZSM-5 catalyst $\left(\mathrm{K}_{0.84} \mathrm{Na}_{0.16} \mathrm{ZSM}-5\right)$. The same phenomenon was observed in the catalysis of LA dehydration to AA by a $\mathrm{K}^{+}$-modified NaY catalyst $[17,20]$. These results suggest that the introduction of an alkali metal efficiently inhibits decarbonylation and decarboxylation of LA to AD. Low selectivities for the other side products such as 2,3-P and PA were observed because the ZSM-5 micropores efficiently suppressed the formation of large molecules. The $\mathrm{NH}_{3} / \mathrm{CO}_{2}$-TPD results (Figs. 1 and 2) suggest that the high AA selectivity and the low selectivity for side products over KZSM-5 are caused by surface synergistic effects between weak acid and base sites and the shape selectivity of ZSM-5. KZSM-5 was therefore selected as the catalyst for further studies because of its superior performance.

The influence of reaction temperature was investigated using KZSM-5. The results (Table 2) show that LA conversion increased with increasing temperature from 350 to $400{ }^{\circ} \mathrm{C}$, and the highest AA selectivity was observed at $365^{\circ} \mathrm{C}$. The catalytic performance of the alkali-metal-modified ZSM-5 zeolites was better than those of sulfate and phosphate catalysts reported in the literature $[11,16]$. The byproduct selectivity also increased with increasing temperature, which indicates that more side

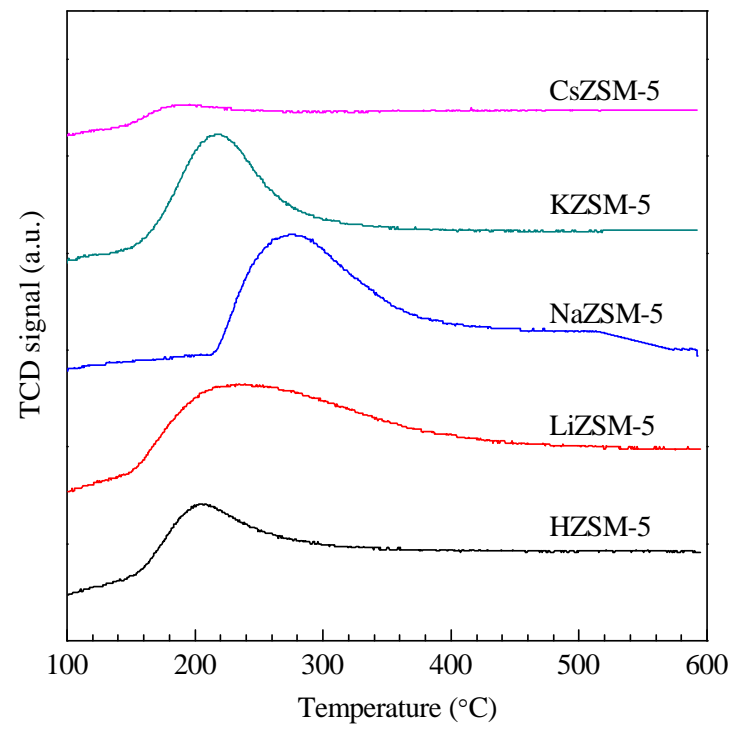

Fig. 2. $\mathrm{CO}_{2}$-TPD profiles of catalysts.

reactions occurred at high temperature. Zeolite-catalyzed reactions should therefore be performed at low temperature to suppress formation of side products.

The effect of the LHSV on LA dehydration was investigated at 2-4 $\mathrm{h}^{-1}$ using the KZSM-5 catalyst. LA conversion decreased from $98.49 \%$ to $90.59 \%$ with increasing LHSV (Table 3). However, the AA selectivity increased slightly to $78.88 \%$ and then decreased to $74.44 \%$, which suggests that a higher LHSV gave high selectivity for AA but low LA conversion. High LA conversion and AA selectivity were achieved at an LHSV of $2 \mathrm{~h}^{-1}$.

\subsubsection{Catalyst stability}

The catalytic effect of KZSM-5 with time on stream (TOS) at $365{ }^{\circ} \mathrm{C}$ is shown in Fig. 3. LA conversion decreased from $97.18 \%$ to $90.59 \%$, whereas the AA selectivity increased from

Table 3

Effect of LHSV on LA dehydration using KZSM-5.

\begin{tabular}{lcccccc}
\hline LHSV & LA conversion & \multicolumn{5}{c}{ Selectivity $(\%)$} \\
\cline { 3 - 7 }$\left(\mathrm{h}^{-1}\right)$ & $(\%)$ & $\mathrm{AA}$ & $\mathrm{AD}$ & $2,3-\mathrm{P}$ & PA & Others \\
\hline 2.0 & 98.49 & 77.13 & 17.28 & 0.96 & 0.78 & 3.85 \\
2.4 & 95.21 & 76.47 & 13.61 & 0.85 & 0.91 & 8.16 \\
3.0 & 92.83 & 78.88 & 16.23 & 0.69 & 0.68 & 3.52 \\
4.0 & 90.59 & 74.44 & 15.53 & 0.63 & 0.67 & 9.03 \\
\hline
\end{tabular}

Reaction conditions: reaction temperature, $365^{\circ} \mathrm{C} ; 40 \mathrm{wt} \%$ lactic acid aqueous solution, $0.8 \mathrm{~mL} / \mathrm{h}$; carrier gas, $50 \mathrm{~mL} / \mathrm{min}$.

Table 2

Effect of reaction temperature on LA dehydration using KZSM-5.

\begin{tabular}{|c|c|c|c|c|c|c|c|c|}
\hline \multirow{2}{*}{$t /{ }^{\circ} \mathrm{C}$} & \multirow{2}{*}{$\begin{array}{c}\text { LA conversion } \\
(\%)\end{array}$} & \multicolumn{5}{|c|}{ Selectivity (\%) } & \multirow{2}{*}{$\begin{array}{l}\text { AA formation rate } \\
\left(\mathrm{mmol} \mathrm{g}^{-1} \text { cat } \mathrm{min}^{-1}\right)\end{array}$} & \multirow{2}{*}{$\begin{array}{l}\text { Carbon deposits } \\
\left(\mathrm{mg} \mathrm{g}^{-1} \text { cat h}^{-1}\right)\end{array}$} \\
\hline & & $\mathrm{AA}$ & $\mathrm{AD}$ & $2,3-P$ & PA & Others & & \\
\hline 350 & 91.24 & 70.29 & 15.17 & 0.66 & 0.64 & 13.24 & 0.23 & 8.75 \\
\hline 365 & 95.21 & 76.47 & 13.61 & 0.85 & 0.91 & 8.16 & 0.36 & 9.38 \\
\hline 375 & 97.70 & 68.74 & 15.16 & 1.07 & 0.57 & 14.46 & 0.33 & 10.52 \\
\hline 400 & 98.82 & 61.29 & 16.12 & 1.77 & 2.00 & 18.82 & 0.29 & 11.25 \\
\hline
\end{tabular}

Reaction conditions: $40 \mathrm{wt} \%$ LA aqueous solution, $0.8 \mathrm{~mL} / \mathrm{h}$; carrier gas, $50 \mathrm{~mL} / \mathrm{min}$; catalyst, $2 \mathrm{~mL}(0.9 \mathrm{~g})$; $\mathrm{TOS}=8 \mathrm{~h}$. 


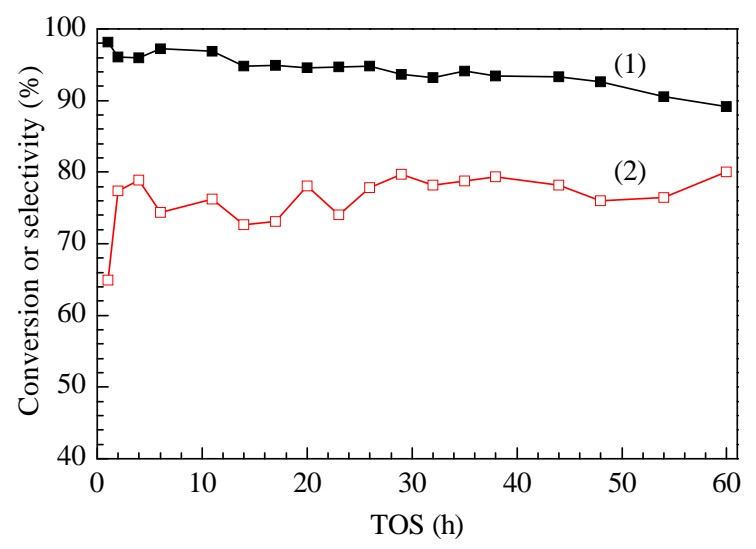

Fig. 3. Stability of KZSM-5 catalyst. (1) LA conversion; (2) AA selectivity. Reaction conditions: $365^{\circ} \mathrm{C}$; $40 \mathrm{wt} \%$ LA aqueous solution, $0.8 \mathrm{~mL} / \mathrm{min}$; carrier gas, $50 \mathrm{~mL} / \mathrm{min}$; catalyst, $2 \mathrm{~mL}(0.9 \mathrm{~g})$.

$64.92 \%$ to $79.37 \%$ for TOS $=60 \mathrm{~h}$. TGA showed that mass loss of the used catalyst was $6 \%$, which suggests that KZSM- 5 gives an excellent anti-coking performance. It was reported in the literature that for modified $\mathrm{NaY}$ zeolites, the LA conversion decreased from $80 \%$ to $65 \%$ and the AA selectivity decreased from $74 \%$ to $55 \%$ for TOS $=5 \mathrm{~h}$. This may be because NaY zeolites have strong surface acid sites and a three-dimensional supercage structure, which facilitates hydrocarbon coking and results in fast deactivation of the catalyst [21]. However, ZSM-5 zeolites give high anti-coking performance because of their moderate acid sites and the absence of supercages [22,23]. The modified ZSM-5 zeolites, in particular KZSM-5, only have weak acid and base sites (Figs. 1 and 2), which are favorable for high AA selectivity and restriction of hydrocarbon coking, therefore they are stable and their activities can be recovered by regeneration.

\subsection{Catalyst characterization}

\subsubsection{Physicochemical properties of catalysts}

The physicochemical properties of the catalysts are shown in Table 4. The modified ZSM-5 catalysts had high surface areas. The surface areas and pore volumes of these catalysts decreased after ion exchange. The reductions were high for HZSM-5 and LiZSM-5, but the introduction of other alkali-metal cations only slightly affected the ZSM-5 structure. The physical

Table 4

Physicochemical properties of catalysts.

\begin{tabular}{|c|c|c|c|c|c|c|}
\hline \multirow{2}{*}{ Catalyst } & \multirow{2}{*}{$\begin{array}{c}\text { Surface } \\
\text { area } \\
\left(\mathrm{m}^{2} / \mathrm{g}\right)\end{array}$} & \multirow{2}{*}{$\begin{array}{c}\text { Pore } \\
\text { volume } \\
\left(\mathrm{cm}^{3} / \mathrm{g}\right)\end{array}$} & \multicolumn{2}{|c|}{$\begin{array}{c}\text { Amount } \\
(\mathrm{mmol} / \mathrm{g})\end{array}$} & \multicolumn{2}{|c|}{$\begin{array}{c}\text { Density } \\
\left(\mu \mathrm{mol} / \mathrm{m}^{2}\right)\end{array}$} \\
\hline & & & $\begin{array}{l}\text { Acid } \\
\text { site }\end{array}$ & $\begin{array}{l}\text { Base } \\
\text { site }\end{array}$ & $\begin{array}{l}\text { Acid } \\
\text { site }\end{array}$ & $\begin{array}{c}\text { Base } \\
\text { site }\end{array}$ \\
\hline ZSM-5 & 287 & 0.293 & - & - & - & - \\
\hline HZSM-5 & 231 & 0.133 & 0.144 & 0.278 & 0.625 & 1.204 \\
\hline LiZSM-5 & 170 & 0.105 & 0.074 & 0.668 & 0.439 & 3.933 \\
\hline NaZSM-5 & 275 & 0.241 & 0.094 & 0.454 & 0.345 & 1.656 \\
\hline KZSM-5 & 263 & 0.262 & 0.037 & 0.295 & 0.142 & 1.125 \\
\hline RbZSM-5 & 249 & 0.235 & - & - & - & - \\
\hline CsZSM-5 & 255 & 0.241 & 0.007 & 0.031 & 0.027 & 0.124 \\
\hline
\end{tabular}

properties of KZSM-5, in particular, hardly changed. The surface acidities and densities decreased in the order $\mathrm{H}->\mathrm{Li}->\mathrm{Na}-$ $>$ K- > Cs-modified ZSM-5. The same trend was observed for surface basicity and density. The introduction of alkali-metal cations decreased the total acid-base number, which improved AA selectivity.

\subsection{2. $X R D$}

XRD was performed to investigate the structures of the modified ZSM-5 zeolites; the patterns are shown in Fig. 4. The powder XRD profiles showed a pure MFI crystal phase, which implies that metal-ion exchange did not affect the crystal phases of the ZSM-5 zeolite. The same peaks were observed from HZSM-5 to KZSM-5, but the peak intensity of the Cs-modified ZSM-5 was slightly lower. This result indicates that the introduction of $\mathrm{Cs}^{+}$destroyed the crystal phase; this explains why the LA conversion achieved using CsZSM-5 was lower than those achieved with the other catalysts.

\subsubsection{Surface acidity and basicity}

In Figs. 1 and 2, the temperature ranges of regions I $\left(100-200{ }^{\circ} \mathrm{C}\right)$, II $\left(200-400{ }^{\circ} \mathrm{C}\right)$, and III $\left(400-600{ }^{\circ} \mathrm{C}\right)$ represent weak, medium, and strong acid/bases, respectively. Previous studies have shown that the surface acidities and basicities of catalysts play key roles in LA dehydration [12]. Table 3 and Fig. 1 show that the strengths and amounts of the acid sites in the metal-modified zeolites decreased in the order $\mathrm{H}->\mathrm{Li}->\mathrm{Na}->$ K- > Cs-ZSM-5. Strong acid sites were eliminated from the surfaces of $\mathrm{Li}^{-}$, Na-, K-, and Cs-ZSM-5, whereas medium acid sites were eliminated by introduction of $\mathrm{K}^{+}$and $\mathrm{Cs}^{+}$. These results suggest that the introduction of alkali metals reduced the surface acidity of the ZSM-5 zeolites to varying degrees. The surface basicities are shown in Fig. 2. Only one peak was observed for all the modified ZSM-5 zeolites. The peak for the KZSM-5 and CsZSM-5 catalysts appeared at around $200{ }^{\circ} \mathrm{C}$ and repre-

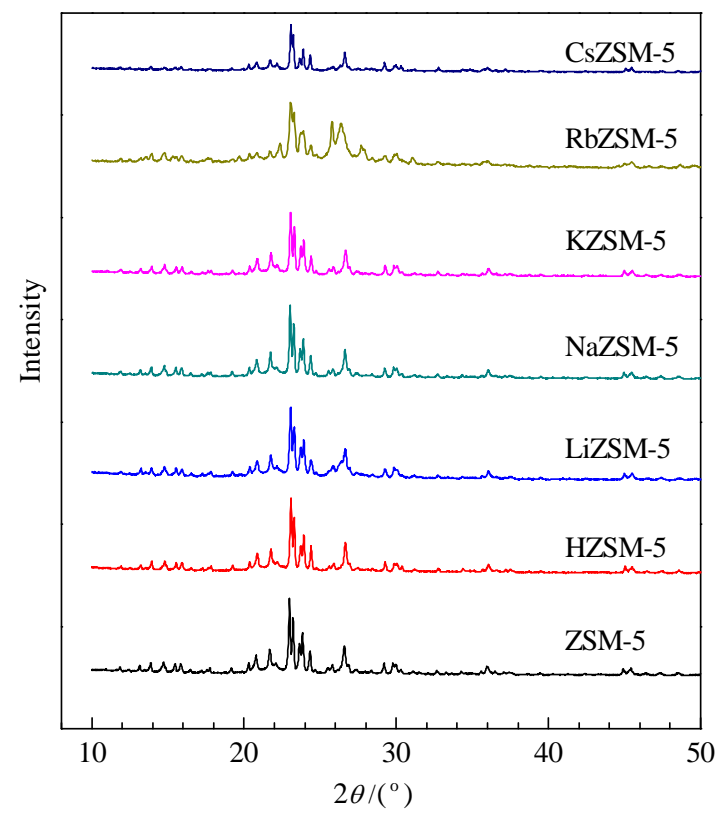

Fig. 4. XRD patterns of ion-exchanged ZSM-5. 


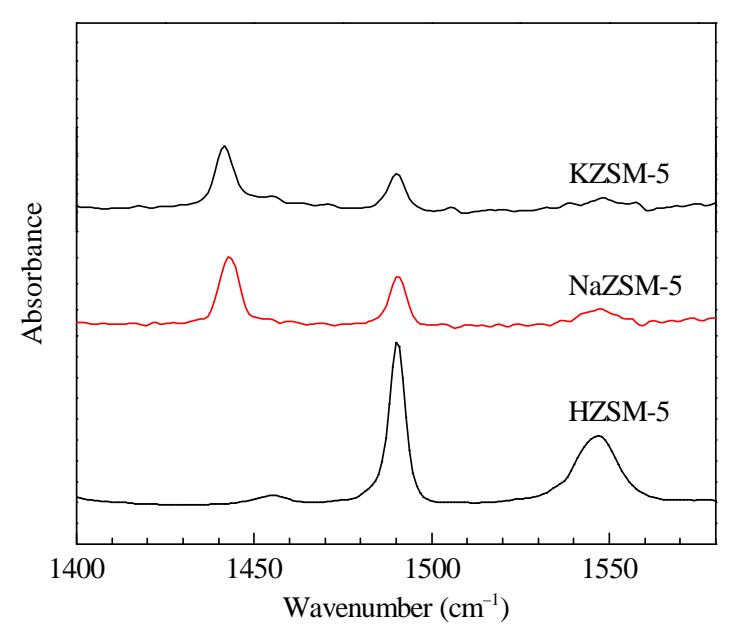

Fig. 5. FTIR spectra of pyridine adsorbed on catalysts.

sented weak base sites. The acid and base sites of KZSM- 5 and CsZSM-5 were weak. The $\mathrm{NH}_{3} / \mathrm{CO}_{2}$-TPD results show that the strengths of the weak acid-base sites matched each other well, which could enhance the acid-base synergistic effect. Previous studies have also shown that moderate acid and base sites favor LA dehydration to AA $[24,25]$. The highest AA selectivity was obtained over the KZSM- 5 and CsZSM- 5 catalysts.

Py-IR was used to study the nature of the acid sites; the results are shown in Fig. 5. The peaks at 1450 and $1549 \mathrm{~cm}^{-1}$ are ascribed to pyridine adsorbed on Lewis acid and Brønsted sites, respectively. The results show that the Brønsted acid peak intensity decreased significantly from HZSM-5 to KZSM-5. In particular, the Brønsted acid peak was almost absent from the KZSM-5 spectrum. However, the Lewis acid peak intensity increased with the introduction of metal cations; this is consistent with a previous report that cations in alkali-metal-exchanged zeolites behave as Lewis acid centers, whereas the framework oxygens behave as Lewis base centers [26]. Decreases in the number of Brønsted acid sites and increases in the number of Lewis acid sites on NaZSM-5 and KZSM-5 were confirmed by $\mathrm{NH}_{3}$-TPD, which showed elimination of strong acid sites and an increase in weak acid sites. Although there was no direct experimental evidence, it can be inferred that the
Lewis acid centers are mainly weak acid sites in the modified ZSM-5 zeolites. An increase in the number of Lewis acid centers can increase the number of weak acid sites, thereby promoting LA dehydration to AA.

\section{Conclusions}

Alkali-metal-cation-modified ZSM-5 zeolites were used to catalyze the dehydration of LA to AA under various reaction conditions. The modified ZSM-5 zeolites showed excellent catalytic activity and high AA selectivity. Among the studied catalysts, the KZSM-5 catalyst gave the best catalytic performance because of the synergistic effect of weak acid-base sites. An increase in the number of Lewis acid sites, which was caused by metal-cation modification of ZSM-5, was beneficial to LA dehydration to AA. The KZSM-5 zeolite had excellent stability in catalytic LA dehydration because of its shape selectivity and the absence of strong acidity and three-dimensional supercages. The KZSM-5 catalyst gave 98\% LA conversion and 77\% AA selectivity under the optimum conditions (i.e., $40 \mathrm{wt} \%$ LA aqueous solution, $365^{\circ} \mathrm{C}$, and LHSV $2 \mathrm{~h}^{-1}$ ).

\section{References}

[1] Corma A, Iborra S, Velty A. Chem Rev, 2007, 107: 2411

[2] Alonso D M, Bond J Q, Dumesic J A. Green Chem, 2010, 12: 1493

[3] Martinez F A C, Balciunas E M, Salgado J M, Gonzalez J M D, Converti A, Pinheira de Souza K. Trends Food Sci Technol, 2013, 30: 70

[4] Dusselier M, Van Wouwe P, Dewaele A, Makshina E, Sels B F. Energy Environ Sci, 2013, 6: 1415

[5] Katryniok B, Paul S, Dumeignil F. Green Chem, 2010, 12: 1910

[6] Korstanje T J, Kleijn H, Jastrzebski J T B H, Klein Gebbink R J M. Green Chem, 2013, 15: 982

[7] Beerthuis R, Granollers M, Brown D R, Salavagione H J, Rothenberg G, Shiju N R. RSC Adv, 2015, 5: 4103

[8] Zhang J F, Feng X Z, Zhao Y L, Ji W J, Au C T. J Ind Eng Chem, 2014, 20: 1353

[9] Lunt J. Polym, Degrad Stab, 1998, 59: 145

[10] Xu X B, Lin J P, Cen P L. Chin J Chem Eng, 2006, 14: 419

[11] Peng J S, Li X L, Tang C M, Bai W. Green Chem, 2014, 16: 108

[12] Hong J H, Lee J M, Kim H, Hwang Y K, Chang J S, Vallgudi S B, Han Y H. Appl Catal A, 2011, 396: 194

[13] Wang H J, Yu D H, Sun P, Yan J, Wang Y, Huang H. Catal Commun,

\section{Graphical Abstract}

Chin. J. Catal., 2015, 36: 1861-1866 doi: 10.1016/S1872-2067(15)60970-6

\section{Alkali-metal-modified ZSM-5 zeolites for improvement of catalytic dehydration of lactic acid to acrylic acid}

Chuan Yuan, Huayan Liu, Zekai Zhang, Hanfeng Lu, Qiulian Zhu, Yinfei Chen*

Zhejiang University of Technology

Lactic acid (LA) conversion of $98 \%$ and $77 \%$ acrylic acid (AA) selectivity were achieved under the operating conditions $40 \mathrm{wt} \% \mathrm{LA}$ aqueous solution, $365^{\circ} \mathrm{C}$, and $2 \mathrm{~h}^{-1}$, using a KZSM-5 catalyst, in LA dehydration to $\mathrm{AA}$, because of the synergistic effect of weak acid-base sites.

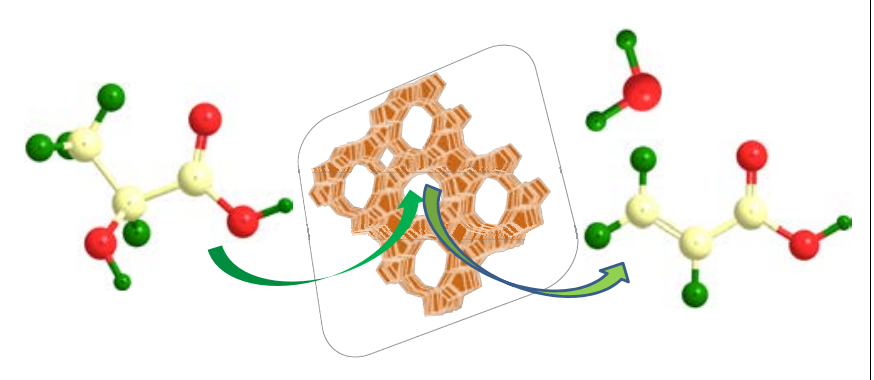


2008, 9: 1799

[14] Zhang J F, Zhao Y L, Feng X Z, Pan M, Zhao J, Ji W J, Au C T. Catal Sci Technol, 2014, 4: 1376

[15] Yan B, Tao L Z, Liang Y, Xu B Q. ChemSusChem, 2014, 7: 1568

[16] Lee J M, Hwang D W, Hwang Y K, Halligudi S B, Chang J S, Han Y H. Catal Commun, 2010, 11: 1176

[17] Sun P, Yu D H, Tang Z C, Li H, Huang H. Ind Eng Chem Res, 2010, 49: 9082

[18] Xia W, Takahashi A, Nakamura I, Shimada H, Fujitani T. J Mol Catal A, 2010, 328: 114

[19] Vishwanathan V, Jun K W, Kim J W, Roh H S. Appl Catal A, 2004, 276: 251
[20] Sun P, Yu D H, Fu K M, Gu M Y, Wang Y, Huang H, Ying H J. Catal Commun, 2009, 10: 1345

[21] Zhang J F, Zhao Y L, Pan M, Feng X Z, Ji W J, Au C T. ACS Catal, 2010, $1: 32$

[22] Satterfield C N. Heterogeneous Catalysis and Industrial Practice. 2nd Ed. New York: McGraw-Hill, 1991. Chapter 7

[23] Jun K W, Lee H S, Roh H S, Park S E. Bull Korean Chem Soc, 2003, 24: 106

[24] Yan J, Yu D H, Li H, Sun P, Huang H. J Rare Earths, 2010, 28: 803

[25] Yan J, Yu D H, Sun P, Huang H. Chin J Catal (间婕, 余定华, 孙鹏, 黄 和. 催化学报), 2011, 32: 405

[26] Deka R C, Hirao K. J Mol Catal A, 2002, 181: 275

\title{
碱金属改性ZSM-5分子篮催化乳酸脱水制丙烯酸
}

\author{
袁 川 ${ }^{\mathrm{a}}$, 刘华彦 ${ }^{\mathrm{a}}$, 张泽凯 ${ }^{\mathrm{a}}$, 卢晗锋 ${ }^{\mathrm{a}}$, 朱秋莲 ${ }^{\mathrm{a}}$, 陈银飞 ${ }^{\mathrm{a}, \mathrm{b}, *}$

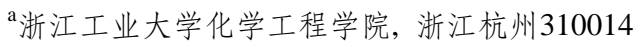

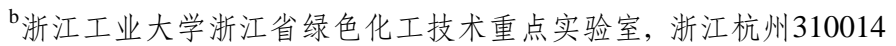

摘要: 乳酸作为一种生物质, 含有羟基和羧基双官能团, 被广泛用于转化为其他化学品, 如乙醛、丙酸、丙烯酸和2,3-戊二酮. 其中, 丙烯酸是一种重要的化工原料, 广泛应用于生产增稠剂、胶黏剂及高吸水性聚丙烯酸酯类树脂, 市场前景广阔, 国内丙烯酸需求量 达 $2000 \mathrm{kt} / \mathrm{a}$. 目前工业上主要采用石油基产品丙烯两步氧化生产丙烯酸, 但石油价格不断上涨, 导致丙烯酸生产成本相应增加. 针对这一问题, 研究者逐渐转向以生物质乳酸为原料, 一步脱水法制备丙烯酸路线, 该方法因环保、经济、符合可持续发展方向而 成为研究热点. 文献中报道的催化剂主要有硫酸盐 $\left(\mathrm{BaSO}_{4}\right)$, 磷酸盐 $\left(\mathrm{Ca}_{3}\left(\mathrm{PO}_{4}\right)_{2}-\mathrm{Ca}_{2}\left(\mathrm{P}_{2} \mathrm{O}_{7}\right)\right), \mathrm{NaY}$ 和 $\beta$ 分子篮. 研究发现, 适中的表面 酸碱性强度和密度是乳酸高选择性转化为丙烯酸的关键. 硫酸盐和磷酸盐催化剂由于表面活性位的缺乏, 必须在高温下才能有 效催化乳酸转化成丙烯酸, 但高温易导致碳氢化合物积炭, 造成原料浪费. 分子筛催化剂具有较高的比表面积和较多的酸碱位分 布, 能够在较低温度下催化醇脱水反应. 其中, $\mathrm{NaY}$ 分子篎催化乳酸脱水时丙烯酸选择性达到 $68 \%$, 但 $\mathrm{NaY}$ 分子篎具有超笼结构, 易造成积炭, 催化剂易失活. 因此, 需选择一种合适的分子笁催化剂, 以抑制积炭.

ZSM-5分子笁具有二维十元环微孔孔道结构(孔径分别为 $0.51 \mathrm{~nm} \times 0.55 \mathrm{~nm}$ 和 $0.53 \mathrm{~nm} \times 0.56 \mathrm{~nm}$ ), 且有可调的酸碱性和较高 的水热稳定性, 被广泛应用于醇脱水(如甲醇制烯烃)和催化裂化反应. 本文采用离子交换法, 利用碱金属 $(\mathrm{Li}, \mathrm{Na}, \mathrm{K}, \mathrm{Rb}$ 和Cs)改性 ZSM-5分子篎用于催化乳酸脱水制丙烯酸. 采用 $X$ 射线衍射、 $\mathrm{NH}_{3}$ 程序升温脱附、 $\mathrm{CO}_{2}$ 程序升温脱附、吡啶吸附红外光谱和 $\mathrm{N}_{2}$ 吸 附等手段表征了催化剂晶相结构、表面酸碱性、比表面积和孔径. 通过气固相反应装置评价了催化剂催化活性、选择性和稳定 性, 并考察了反应温度和空速等工艺条件对催化反应的影响.

结果表明,碱金属改性的ZSM-5分子篎, 晶相结构基本未受到破坏, 比表面积下降, 表面酸碱性强度减弱,酸碱位密度降低. 在 催化乳酸脱水制丙烯酸过程中, 碱金属改性的ZSM-5催化剂表现出优异的催化活性, 使乳酸较高选择性地转化成丙烯酸. 其中, $\mathrm{K}^{+}$交换后的KZSM-5催化剂催化活性和丙烯酸选择性最高, 在最优反应条件(乳酸浓度 $40 \mathrm{wt} \%$, 反应温度 $365{ }^{\circ} \mathrm{C}$, 液体空速(LHSV) $\left.2 \mathrm{~h}^{-1}\right)$ 下, 乳酸转化率可达 $98 \%$, 丙烯酸选择性可达 $77 \%$. 结合表征结果可知, 弱酸及弱碱位的协同作用能够提高丙烯酸选择性. 同 时, 碱金属的引入使催化剂表面Lewis酸位增多, 该酸性位有利于乳酸脱水生成丙烯酸. 另外, ZSM-5分子笁由于其特殊的孔道结 构和强酸位的缺失, 在催化过程中很好地抑制了原料和产物的积炭, 使其具有良好的催化稳定性, 催化剂寿命长, 具有良好的工业 化应用前景.

关键词: ZSM-5分子篮; 碱金属; 乳酸; 丙烯酸; 脱水

收稿日期: 2015-06-03. 接受日期: 2015-09-06. 出版日期: 2015-11-20.

*通讯联系人. 电话: +86-13606643528; 电子信箱: yinfei.chen@gmail.com

本文的英文电子版由Elsevier出版社在ScienceDirect上出版(http://www.sciencedirect.com/science/journal/18722067). 